This is an electronic reprint of the original article. This reprint may differ from the original in pagination and typographic detail.

Author(s): Yada, Akie; Savolainen, Hannu

Title: Japanese in-service teachers' attitudes toward inclusive education and self-efficacy for inclusive practices

Year: $\quad 2017$

Version:

Please cite the original version:

Yada, A., \& Savolainen, H. (2017). Japanese in-service teachers' attitudes toward inclusive education and self-efficacy for inclusive practices. Teaching and Teacher Education, 64, 222-229. https://doi.org/10.1016/j.tate.2017.02.005

All material supplied via JYX is protected by copyright and other intellectual property rights, and duplication or sale of all or part of any of the repository collections is not permitted, except that material may be duplicated by you for your research use or educational purposes in electronic or print form. You must obtain permission for any other use. Electronic or print copies may not be offered, whether for sale or otherwise to anyone who is not an authorised user. 


\title{
Japanese in-service teachers' attitudes toward inclusive education and self-efficacy for inclusive practices
}

\begin{abstract}
Using a sample of 359 in-service teachers, this study examines Japanese teachers' attitudes toward inclusive education and their self-efficacy for inclusive practices. The results indicate that although teachers' sentiments toward disabilities were generally positive, the teachers had some concerns about implementing inclusive education in their classroom. The overall level of self-efficacy was relatively low in the Japanese sample compared to that of other countries, particularly in relation to managing problematic student behavior. Self-efficacy regarding managing behavior and collaboration was related to overall attitudes toward inclusive education. The findings can enable useful insights in developing pre-service and in-service teacher education.
\end{abstract}

Keywords: inclusive education; Japanese teacher; attitude; self-efficacy. 


\section{Introduction}

Since the Salamanca Statement on Principles (UNESCO, 1994), inclusive education has become the mainstream in global education policy. As a consequence, including students with diverse educational needs in mainstream schools has become the center of international attention in the planning of educational legislation and policy (Savolainen, Engelbrecht, Nel, \& Malinen, 2012; Sharma, Loreman, \& Forlin, 2012).

However, the definition of inclusive education is ambiguous and has been vastly debated around the world. According to the definition provided by UNESCO (2005, p.13), inclusive education is "a process of addressing and responding to the diversity of needs of all learners through increasing participation in learning, cultures and communities, and reducing exclusion within and from education." Even though inclusive education can be regarded as aiming at an equity agenda for all students, it is often understood as concerning only students with disabilities and those requiring special needs education (Artiles \& Kozleski, 2007; Malinen \& Savolainen, 2008; Waitoller \& Artiles, 2013). On the basis of Oliver's (1996) writings, Graham and Jahnukainen (2011) simply described the difference between traditional special education and inclusive education in that the former locates the "problem" in an individual with a disability, who must be supported to "fit in" the social institutions pre-designed by others with able bodies, while the latter focuses on barriers that produce the disability, thereby constructing "the disabled" (Oliver, 1996). We understand inclusive education as making an effort to construct school systems that welcome all children (Savolainen, 2009). However, from a Japanese perspective, the term "inclusive education" is generally understood to mean including children with disabilities into mainstream schooling (Forlin, Kawai, \& Higuchi, 2015). Therefore, in the current study, inclusive education is perhaps best defined as including children with disabilities into regular classrooms.

Furthermore, although it has been universally agreed that inclusive education enables equal opportunities and access for all students, educational policies and reform processes are different from country to country for reasons of culture and history (Savolainen et al., 2012). To take Japan as an example, since the government has only recently introduced a new scheme on inclusive education, it is doubtful whether teachers are ready for this new movement (Forlin, 2013). In addition, there are

considerable gaps between the concepts of the policies and the actual practices (Miyoshi, 2009), and there are several challenges in implementing inclusive education, such as the lack of physical and personal resources. Comparative analyses conducted within a cultural-historical framework can give us a critical insight into the complex and dynamic local situation in which inclusive education is implemented (Engelbrecht, Savolainen, Nel, \& Malinen, 2013). Some studies compare several 
countries in the context of inclusive education (e.g., Jahnukainen, 2011; Takala, Haussttatter, Ahl, \& Head, 2012). However, few international studies focus on Japan. Thus, the present study explores the Japanese context in relation to inclusive education, particularly from the point of view of teachers. More specifically, the focus of this paper is on Japanese teachers' attitudes toward inclusive education and their self-efficacy for inclusive practices and the implications for the practice of inclusive education in Japan.

\subsection{Inclusive education in Japan}

In recent years, there has been an increasing amount of attention on inclusive education in Japan. This has been influenced by an international campaign supporting inclusion, such as the Convention on the Rights of the Child (United Nations, 1989), the World Declaration on Education for All and the Framework for Action to Meet Basic Learning Needs (UNESCO, 1990), the Dakar Framework for Action (UNESCO, 2000), and the Salamanca Statement and Framework for Action on Special Needs Education (UNESCO, 1994). The Japanese government called for the partial revision of Gakkokyoikuho (the School Education Law) in April 2007 and promoted educational reform. The government replaced Tokushukyoiku (segregated special education), in which education is separately delivered on the basis of the type of disability in special places, with Tokubetsushienkyoiku (special needs education), in which appropriate support is given to each child with diverse educational needs (Central Council for Education, 2005). Since then, a new support system has been developed, which includes, for example, an establishment of a school committee and an appointment of special needs education coordinator in regular schools for children with diverse educational needs (Fujii, 2014). Moreover, the Japanese government signed the Convention on the Rights of Persons with Disabilities (United Nations, 2006) in September 2007, and Shogaishakihonho (the Basic Law for Persons with Disabilities) was amended accordingly in August 2011. In response to this, the Committee of Elementary and Lower Secondary Education (2012) submitted a report about the development of special needs education in order to implement inclusive education. This report indicated the following points: (1) ways of deciding study placement; (2) repletion of reasonable accommodation and basic environmental improvement; (3) cooperation between schools and related organizations; (4) development of exchange studies; and (5) enrichment of teachers' expertise (Fujii, 2014).

Thus far, political change regarding inclusive education has proceeded rapidly in Japan. However, it has not been properly implemented in practice, and there are several challenges involved. First, one of the most crucial barriers to inclusive education in Japan is that even though the government has promoted a special needs education system for inclusive education, Japanese special needs 
education is still delivered mainly in a segregated manner. There are 31,507 special classes and 1,049 special schools at the primary and secondary level, and the number of special classes and special schools is increasing annually (Ministry of Education, Culture, Sports, Science and Technology, 2012). This phenomenon - the growing rate of enrollment for special schools and special classes - signals a diversion away from inclusive education (Miyoshi, 2009). Furthermore, Miyoshi (2009) held the view that the operation of special needs education has increased the number of children who are certified as "children with disabilities" and made a distinction between children with disabilities and children without disabilities.

Second, large class sizes are one of the notable challenges in Japan. The average number of students in primary education was 28 per class and 30 per class at the secondary level (OECD, 2011). It is said that about $6.3 \%$ of students in regular classes have some kind of developmental disability, such as learning disability (LD), attention deficit hyperactivity disorder (ADHD), or high-functioning autism (Committee of Elementary and Lower Secondary Education, 2012). To date, several studies have reported that the support system for children with disabilities in regular classes is underdeveloped (e.g., Hamaya, 2006; Hirose \& Tojo, 2002). For instance, Ueno and Nakamura (2011) examined teachers' awareness of inclusive education and concluded that teachers found it difficult to implement inclusive education under the current inadequate support system.

Third, several studies have reported that Japanese teachers' expertise is not sufficient to carry out inclusive practices because they have not received adequate teacher training. According to the Committee of Elementary and Lower Secondary Education (2012), while every teacher is required to have basic knowledge and skills in special needs education, specialized courses in special needs education are not compulsory in current teacher education programs. Furthermore, despite the new policies, there are still few courses regarding inclusive education in Japanese teacher education programs for the regular teacher certificate (Forlin et al., 2015). Even though teachers' interest in inclusive education is relatively high and teachers realize that such education is necessary, their knowledge level is low, and they experience considerable anxiety about including children with disabilities in their classrooms (Ueno \& Nakamura, 2011). Fujii (2014) carried out a survey exploring teachers' awareness of keywords relating to special needs education and inclusive education. The findings showed that the awareness level of an "inclusive education system" was lower, suggesting that it was necessary to enrich teacher training in inclusive education inside and outside of school.

Finally, collaboration with other school staff or parents appears to be an effective way of learning 
from the experience of others and improving teachers' expertise. However, since Japanese teachers have so many duties in addition to teaching, they do not have enough time for collaboration. According to the National Institute for Educational Policy Research (NIER, 2014), although Japanese teachers' working time of 53.9 hours per week is the longest among OECD countries, where the average is 38.3 hours, teachers spend more time in extracurricular activities and clerical work and less time collaborating with parents. Ogiso and Tsuzuki (2016) suggested that since teachers' time is completely taken up with regular duties, it is difficult to independently include children with disabilities and that the improvement of the consultation and supervision system on a daily basis in each school is indispensable in Japan.

\subsection{Teachers' attitudes toward inclusive education}

Attitude studies have a long-standing history, and the importance of the concept continues in the area of social psychology. Early on, Allport (1935) maintained that "the concept of attitude is probably the most distinctive and indispensable concept." The term "attitude" is generally understood as an evaluation of attitude objects containing anything a person may hold in mind, which can be concrete or abstract (Bohner \& Dickel, 2011). However, proper definitions have been actively debated, with the adoption of different views on whether attitudes are trait-like dispositions stored permanently in the memory or momentary judgments constructed from information (Gawronski, 2007). Since the aim of this study is not to delve into a discussion of the precise definition of attitude, it adopts the definition suggested by Eagly and Chaiken (1993, p.1), who saw the concept as "a psychological tendency that is expressed by evaluating a particular entity with some degree of favor or disfavor."

In order to meet the diverse educational needs of students, schools and teachers need to change and adapt their practices (Kinsella \& Senior, 2008). It has been argued that teachers are required to have positive attitudes toward inclusive education as well as the appropriate skills and knowledge if they are to successfully carry out inclusive practices (Avramidis \& Norwich, 2002; Forlin, Cedillo, Romero-Contreras, Fletcher, \& Hernandez, 2010; Ryan \& Gottfried, 2012). Thus, a line of research has focused on teachers' attitudes toward inclusive education. Avramidis and Norwich (2002) pointed out that even though teachers have positive attitudes toward inclusive education, they do not agree on "total inclusion" and that attitudes are strongly influenced by child-related variables (e.g., the nature of students' disabilities) and educational environment-related variables (e.g., the availability of physical and human support).

In addition, some studies have suggested that attitudes toward inclusive education differ by country. 
For instance, previous research findings have indicated that teachers' attitudes toward inclusive education tend to be more negative in non-Western countries (Alghazo \& Gaad, 2004; Malinen \& Savolainen, 2008). Unfortunately, there are scarcely any studies on teachers' attitudes toward inclusive education in Japan. Forlin (2013) examined pre-service teachers' understanding of and attitudes toward inclusive education in a Japanese university. It was found that because of teachers' lack of knowledge and skills to teach students with special educational needs, pre-service teachers experience great levels of anxiety about workload increases due to these students being included in their future classrooms. Thus, in order to more positively develop pre-service teachers' attitudes toward inclusive education, more work is required to ensure that pre-service teachers gain a better understanding of inclusion and that they are presented with opportunities to explore their feelings about inclusive education (Forlin, 2013).

\subsection{Teachers' self-efficacy for inclusive practices}

Bandura (1977) first introduced the concept of self-efficacy, and more recently, he illustrated it as the main concept in his social cognitive theory (Bandura, 2001). He defined self-efficacy as an individual's belief that s/he can produce desired effects in a specific situation and the belief influences her/his cognitive, motivational, affective, and decisional processes (Bandura, 2006). Self-efficacy beliefs consist of four main sources: (1) mastery experiences in which a person has previous experience being successful in certain tasks; (2) vicarious experiences where a person observes similar people who are capable of performing the task; (3) social persuasion by others can strengthen one's belief in completing the task successfully; and (4) somatic and emotional states that are analyzed when a person's efficacy beliefs are formed (Bandura, 1997; Klassen, 2004). Bandura (1997) indicated that mastery experience was the most powerful source of self-efficacy beliefs. Any or all of these four sources may be influenced by the cultural context or dimension, such as collectivism or individualism (Klassen, 2004).

Over the past 30 years, the concept of self-efficacy has been expanded to focus on teachers' feelings of confidence, and the result has been a large volume of published studies regarding teacher efficacy. The term "teacher efficacy" is generally understood to mean teachers' belief or conviction that they can influence their students' learning efficiently, even though these students might have difficulty or lower motivation (Guskey \& Passaro, 1994). Bandura (1997) suggested that teachers' beliefs in their efficacy affect not only students' academic development but also their general orientation toward educational processes. Gibson and Dembo (1984) found that high-efficacy teachers are more persistent in correcting students' incorrect answers and never give student feedback in the form of criticism. In addition, teachers with high self-efficacy can lead students to correct responses more 
effectively (Gibson \& Dembo, 1984).

Recently, there has been an increasing amount of literature on teachers' self-efficacy for inclusive practices. According to Forlin (2013), it is crucial for teachers to be confident in their own knowledge, skills, and abilities in practicing inclusive education so as to successfully implement the inclusive approach. Although there is much research on teachers' self-efficacy in Western countries, such research regarding non-Western countries is limited (Sharma et al., 2012), and Japan is no exception. Yoshitoshi (2014) investigated teachers' sense of self-efficacy for inclusive practices among 59 high school teachers and concluded that Japanese high school teachers had low self-efficacy for inclusive practices because of a lack of training. Few studies have focused on teachers' self-efficacy for inclusive practices among primary or lower secondary school teachers in Japan, even though it has been suggested that inclusive education would be an important starting point for children at an early age (Oohara, Hirota, \& Suzuki, 2011).

\subsection{The relationship between teachers' attitudes toward inclusive education and self-efficacy for inclusive practices}

Attitudes and self-efficacy are the two main concepts examined in this study and are associated with successfully implementing the inclusive approach. Previous studies have reported a positive relationship between teachers' attitudes toward inclusive education and self-efficacy for inclusive practices (Malinen, Savolainen, \& Xu, 2012; Meijer \& Foster, 1988; Savolainen et al., 2012; Weisel $\&$ Dror, 2006). According to Meijer and Foster (1988), Dutch teachers with high self-efficacy are likely to see students with learning or behavioral problems as less problematic and in less in need of referral. Furthermore, it was conclusively shown that Israeli teachers' sense of efficacy is the only crucial factor affecting teachers' attitudes toward inclusive education (Weisel \& Dror, 2006). A recent study by Malinen et al. (2012) examined Chinese teachers' self-efficacy and reported that self-efficacy in collaboration is the single most important factor predicting teachers' attitudes toward inclusive education.

\subsection{Research questions}

The main purpose of this study is to investigate Japanese teachers' general attitudes toward inclusive education and their self-efficacy for inclusive practices. In addition, the study examines whether Japanese teachers' self-efficacy relates to attitudes toward inclusive education. An additional aim of this research is to identify which types of self-efficacy and whether two demographic variables (teaching experience and gender) predict attitudes if there are relationships between them. According to these aims, the study addresses the following questions below: 
1) What is the level of Japanese teachers' overall and specific attitudes toward inclusive education?

2) What is the level of Japanese teachers' overall and specific self-efficacy for inclusive practices?

3) Does Japanese teachers' self-efficacy for inclusive practices correlate with their attitudes toward inclusive education?

4) Can the three types of self-efficacy for inclusive practices along with the two demographic variables (teaching experience and gender) predict teachers' attitudes toward inclusive education?

\section{Method}

\subsection{Research method}

A survey approach was employed in the current study. It was chosen because information from a sample of entities enables us to construct quantitative descriptions of larger populations (Groves et al., 2009). The questionnaire design was based on an existing study (Savolainen et al., 2012); thus, the Japanese data could be compared with those of other countries. To collect the data, a convenience sampling method was adopted, in which the authors asked the first contact persons, such as professors in universities who had connections with principals or teachers, to deliver the questionnaire and to introduce it to others.

\subsection{Participants}

The data were obtained from 359 primary and secondary in-service school teachers working in Japanese private and public schools. Three-fourths of the participants $(252,72.2 \%)$ worked in public or national schools, and 96 (27.5\%) worked in private schools. The schools were located in several different prefectures in the eastern and western parts of Japan, including the Tokyo metropolis and the prefectures of Kanagawa, Yamaguchi, Kagoshima, Chiba, Saitama, Kochi, Miyazaki, and Fukui. In addition, 157 (43.7\%) participants were male, 192 (53.5\%) were female, and 10 (2.8\%) of them did not mention their gender. The teachers' were between the ages of 22 and 65, and the average age was $42.41(\mathrm{SD}=11.82)$. They had an average of $18.42(\mathrm{SD}=11.92)$ years' teaching experience. When asked what grade level they taught, the participants provided the following answers: 189 (52.6\%) were in primary school (grades 1 to 6$), 77$ (21.4\%) were in lower secondary school (grades 7 to 9$), 55$ (15.3\%) were in upper secondary school (grades 10 to 12$), 1(0.3 \%)$ was in a combined primary and lower secondary school (grades 1 to 9 ), and $8(2.2 \%)$ were in combined lower and upper secondary schools (grades 7 to 12). The participants also indicated their position in their schools. The majority of them $(287,79.9 \%)$ worked as regular teachers; 15 (4.2\%) were principals; 17 (4.7\%) were vice principals; 19 (5.3\%) were chief teachers; and 10 (2.8\%) were school nurses 
with teaching licenses. Furthermore, 349 of the participants mentioned their highest degree level obtained, and most $(284,79.1 \%)$ had a bachelor's degree. Among the remainder of the participants, 17 (4.7\%) graduated from junior colleges, $46(12.8 \%)$ had a master's degree, and $2(0.6 \%)$ had a doctoral degree.

\subsection{Research instruments}

The data were collected using an instrument consisting of two scales. The first was the Sentiments, Attitudes, and Concerns about Inclusive Education Revised (SACIE-R) scale (Forlin, Earle, Loreman, \& Sharma, 2011), which was designed to measure pre-service teachers' perception of the three constructs of inclusive education. It contained 13 items, and four response anchors from "strongly disagree" to "strongly agree." While the SACIE-R scale originally consisted of 15 items, two items were removed in the current study because a previous study indicated that they ("I dread the thought that I could eventually end up with a disability" and "I would feel terrible if I had a disability") did not fit well with a factor model relating to attitudes (Savolainen et al., 2012). Several SACIE-R items are required to use reverse scoring in analyses. Higher SACIE-R scale scores imply more positive attitudes toward inclusive education. The alpha coefficient for the overall scale was moderate in the current study ( $\alpha=0.75$ ). The scale has three sub-scales: "Sentiments," "Attitudes," and "Concerns," which were consistent with previous studies (Forlin et al., 2011; Savolainen et al., 2012). For the three sub-scales, the alpha values ranged from .71 to .78, which were acceptable.

The second scale was the Teacher Efficacy for Inclusive Practices (TEIP) scale (Sharma et al., 2012), which was developed to assess teachers' self-efficacy for inclusive practices. This scale involved 18 items with six response anchors ranging from "strongly disagree" to "strongly agree." Higher scores on the TEIP scale indicate participants' higher efficacy in implementing inclusive practices. In the current study, the TEIP scale had a high reliability, and the alpha coefficient for the scale was .93. Previous studies have noted that this scale also had three sub-scales: "Efficacy to use inclusive instructions," "Efficacy in managing behavior," and "Efficacy in collaboration" (Savolainen et al., 2012; Sharma et al., 2012). The Cronbach's alpha of these sub-scales was good, ranging from .83 to .88 .

\subsection{Translation of the questionnaires}

Whole sections of the instrument were originally written in English, and it was first translated into Japanese by the author whose native language is Japanese, but who is fluent in English. A native Japanese master's degree student in education, who is fluent in English, checked the content and quality of the translation. Finally, a licensed guide interpreter, who had taught in Japanese high 
schools as an English teacher, proofread the translated Japanese version of the instrument, and corrections were agreed by the author to ensure maximum similarity with the original instrument.

The SACIE-R and TEIP scales had already been translated into Japanese (Forlin, 2013; Yoshitoshi, 2014), and these Japanese versions were used as references. However, several items of the SACIE-R scale used in Forlin's (2013) study were revised, and some of the content was changed, so the original version of the SACIE-R scale was adopted in the current study. For the TEIP scale, the style of writing in some items was marginally altered to fit more into the natural context of Japanese teachers. These changes were also discussed between the author and the interpreter.

\subsection{Ethical issues}

Ethical issues were taken into account in light of the official Finnish guidelines on Responsible Conduct of Research and Procedures for Handling Allegations of Misconduct in Finland (Finnish Advisory Board on Research Integrity, 2012). These guidelines match the ethical guidelines of Japanese research institutions. The purposes and nature of the study and the confidentiality of the data were explained to the participants by means of an information letter. Participation was voluntary, and participants had the right to withdraw at any time. Even though they were asked to answer some personal background information, such as their profession and educational background, none of the information that might identify them was presented in the study.

\subsection{Data analysis}

The data analysis was conducted using the SPSS software (IBM, 2012) version 20. First, the reliability of the overall scales and sub-scales was analyzed using Cronbach's alpha. Second, the mean scores of the overall scales and sub-scales with confidence intervals were used to assess the level of Japanese teachers' attitudes toward inclusive education and their self-efficacy for inclusive practices. Furthermore, in order to analyze the relationships between teachers' attitudes and self-efficacy, a series of correlations were calculated. Finally, regression analyses were conducted to test how the three different types of self-efficacy as well as some teachers' background variables jointly predict teachers' attitudes toward inclusive education.

\section{Results}

\subsection{The level of Japanese teachers' attitudes toward inclusive education}

The Japanese teachers' overall attitudes toward inclusive education were slightly above the neutral midpoint of the scale, which ranged from 1 to $4(M=2.69)$, thus indicating that the teachers did not express extreme attitudes for or against inclusive education. The teachers' average SACIE-R score 
varied statistically significantly across the three sub-dimensions of attitudes, as indicated by the non-overlapping $99 \%$ confidence intervals. The most positive attitude reported was on sentiments about interacting with a person with disabilities $(M=3.38)$. Their attitudes about including children with disabilities in mainstream classes were close to the neutral midpoint of the scale $(M=2.58)$. Their concerns about what would happen if children with disabilities were included in their classes were the lowest $(M=2.37)$ among the three sub-scales (Table 1).

Table 1. SACIE-R scale overall and sub-scale scores and $99 \%$ confidence interval (CI) of means

\begin{tabular}{lccc}
\hline & Mean & Lower CI & Upper CI \\
\hline SACIE-R & 2.69 & 2.63 & 2.74 \\
Sentiments & 3.38 & 3.30 & 3.46 \\
Attitudes & 2.58 & 2.50 & 2.66 \\
Concerns & 2.37 & 2.29 & 2.44 \\
\hline
\end{tabular}

\subsection{The level of Japanese teachers' self-efficacy for inclusive practices}

The Japanese teachers' overall self-efficacy for inclusive practices was at a low level $(M=3.74$ on the TEIP scale, which ranged from 1 to 6) compared to the results of previous studies conducted in other countries (e.g., according to Savolainen et al. (2012), in Finland, the mean score was 4.53, and in South Africa, the mean score was 4.63). The teachers' average level on the TEIP score varied statistically significantly across the three sub-dimensions of self-efficacy, as indicated by the non-overlapping 99\% confidence intervals. The Japanese teachers' level of self-efficacy in using inclusive instruction was the highest of the three sub-dimensions $(M=3.84)$, while they were least confident in managing students' problematic behavior in their classroom $(M=3.55)$ (Table 2).

Table 2. TEIP scale overall and sub-scale scores and 99\% confidence interval (CI) of means

\begin{tabular}{lccc}
\hline & Mean & Lower CI & Upper CI \\
\hline TEIP & 3.74 & 3.65 & 3.83 \\
Inclusive instruction & 3.84 & 3.75 & 3.94 \\
Collaboration & 3.79 & 3.68 & 3.89 \\
Managing behavior & 3.55 & 3.44 & 3.66 \\
\hline
\end{tabular}

\subsection{Correlation between Japanese teachers' self-efficacy for inclusive practices and attitudes toward inclusive education}


Japanese teachers' overall self-efficacy for inclusive practices correlated statistically significantly $(p$ $<.01)$ with overall attitudes and the three sub-scales. The highest correlation was found between the two full scales $(r=0.396)$. Moreover, overall self-efficacy for inclusive practices correlated moderately with concerns $(r=0.342)$. Of the three sub-scales of self-efficacy for inclusive practices, self-efficacy in managing behavior correlated most strongly with overall attitudes $(r=0.357)$, and it was especially correlated with concerns $(r=0.359)$. Further, self-efficacy in collaboration was moderately correlated with overall attitudes $(r=0.355)$ (Table 3$)$.

Table 3. Pearson correlations between the SACIE-R and TEIP scales' overall scores and sub-scale

\begin{tabular}{|c|c|c|c|c|c|c|c|}
\hline & 1 & 2 & 3 & 4 & 5 & 6 & 7 \\
\hline 1. SACIE-R all & - & & & & & & \\
\hline 2. Sentiments & $.629^{* * *}$ & - & & & & & \\
\hline 3. Attitudes & $.626^{* * *}$ & .056 & - & & & & \\
\hline 4. Concerns & $.776^{* * *}$ & $.482^{* * *}$ & .096 & - & & & \\
\hline 5. TEIP all & $.396^{* * *}$ & $.286^{* * *}$ & $.189^{* * *}$ & $.342^{* * *}$ & - & & \\
\hline 6. Inclusive instruction & $.344^{* * *}$ & $.265^{* * *}$ & $.166^{* *}$ & $.287^{* * *}$ & $.939^{* * *}$ & - & \\
\hline 7. Managing behavior & $.357^{* * *}$ & $.248^{* * *}$ & $.131^{*}$ & $.359^{* * *}$ & $.855^{* * *}$ & $.742^{* * *}$ & - \\
\hline 8. Collaboration & $.355^{* * *}$ & $.248^{* * *}$ & $.203^{* * *}$ & $.270^{* * *}$ & $.869^{* * *}$ & $.744^{* * *}$ & $.560^{* * *}$ \\
\hline
\end{tabular}

Notes: $* p<.05, * * p<.01, * * * p<.001$.

\subsection{Self-efficacy sub-dimensions as predictors of attitudes toward inclusive education}

Using multiple regression analysis, the three different types of self-efficacy were tested as predictors of general attitudes toward inclusive education. Furthermore, two demographic variables (teaching experience and gender) were tested as independent variables to ascertain how they affected overall attitudes toward inclusive education. The result showed that efficacy in collaboration was the strongest predictor of general attitudes toward inclusive education $(\beta=0.254, p<.01)$. In addition, the beta value for efficacy in managing behavior was slightly lower $(\beta=0.232, p<.01)$, but it was also a powerful predictor of general attitudes toward inclusive education. For the teachers' two demographic information variables, only their teaching experience $(\beta=-0.107, p<.05)$ had an effect on general attitudes. The effect was negative, indicating that the teachers with longer periods of experience had slightly more negative attitudes (Table 4). 
Table 4. Regression models predicting overall attitudes toward inclusive education

\begin{tabular}{lcc}
\hline & Std Beta & t-value \\
\hline Efficacy in inclusive instruction & 0.006 & 0.060 \\
Efficacy in managing behavior & 0.232 & $2.959^{* *}$ \\
Efficacy in collaboration & 0.254 & $3.207^{* *}$ \\
Teaching experience & -0.107 & $-2.006^{*}$ \\
Gender & 0.027 & 0.507 \\
Model statistics & $F_{5,323}=13.548^{* * *}$ \\
$R^{2}$ & \multicolumn{2}{c}{0.1743} \\
\hline
\end{tabular}

Notes: $* p<.05, * * p<.01, * * * p<.001$.

\section{Discussion}

The two measures used in the current study (the SACIE-R and TEIP scales) were reliable instruments in the Japanese samples, and their profiles replicated those of previous studies (Malinen et al., 2012; Savolainen et al., 2012). The results indicated that Japanese teachers' overall attitudes toward inclusive education were somewhat neutral. It has been suggested that teachers' attitudes toward inclusive education might be more negative in non-Western countries (Alghazo \& Gaad, 2004; Malinen \& Savolainen, 2008). However, this did not appear to be the case in the current study. What is more, even though teachers have neutral attitudes toward inclusive education in several countries, attitude profiles vary from country to country (Savolainen et al., 2012). The Japanese attitude profiles resembled those of Finland, where sentiments about interacting with persons with disabilities were significantly positive, but regarding their concerns about including children with disabilities in their own classrooms, the attitudes were relatively negative (Savolainen et al., 2012). This finding further supports the idea that the teachers were more critical about including children with disabilities in their own classrooms (Savolainen et al., 2012). It corroborates Ueno and Nakamura's (2011) research, which showed that Japanese teachers experienced high levels of anxiety about including children with disabilities in their classrooms, even though many of the teachers thought inclusive education was necessary.

Overall self-efficacy for inclusive practice was considerably low in the Japanese sample compared to those in other countries such as Finland and South Africa (Savolainen et al., 2012). This result supports that of Yoshitoshi's (2014) study, which showed that Japanese high school teachers had low self-efficacy for inclusive practices. As Yoshitoshi (2014) suggested, inadequate training in inclusive practices might be one possible explanation for this result. However, NIER (2014) found that, 
generally, Japanese teachers have low self-efficacy for their practice, and it might be because they have higher expectations or that Japanese people have a greater disposition to be humble. Thus, these data must be interpreted with caution, and cultural and historical background must be considered. Further study is needed to explain why Japanese teachers' self-efficacy for inclusive practices is low. The self-efficacy profile in the current study was similar to that in the Finnish sample in which the level of self-efficacy was highest in implementing inclusive instruction, although those teachers had the least confidence in managing behavior (Savolainen et al., 2012). This finding was in line with that of a previous Japanese study, which concluded that Japanese teachers were concerned about students' problematic behavior in classrooms, regardless of academic achievement (Hirose \& Tojo, 2002).

The third question sought to determine whether there was a relationship between Japanese teachers' self-efficacy for inclusive practice and attitudes toward inclusive education. There was a moderate correlation between self-efficacy and attitudes, as suggested by some previous studies (Malinen et al., 2012; Meijer \& Foster, 1988; Savolainen et al., 2012; Weisel \& Dror, 2006). In addition, self-efficacy was especially correlated with teachers' concerns. This result indicates that teachers who believed themselves to be more capable of implementing inclusive practices were less concerned about including learners with disabilities in their own classrooms. Moreover, self-efficacy in managing behavior had the strongest correlation with attitudes in the current study. Thus, teachers with stronger beliefs in their ability to manage students' problematic behavior had more positive attitudes toward inclusive education.

The final question aimed to identify the relative importance of different types of self-efficacy and two demographic variables (teaching experience and gender) as predictors of Japanese teachers' attitudes toward inclusive education. It is interesting to note that the rate of female participants in this study (53.5\%) was low compared to that of other countries, such as in Finland (78.3\%), South Africa (82.1\%), and China (85.4\%) (Malinen et al., 2012; Savolainen et al., 2012). However, the results of this study failed to show teachers' gender as related to their attitudes toward inclusive education. Teaching experience had a relatively small but significant effect on attitudes toward inclusive education. This result corroborates those of a previous study indicating that teachers with more teaching experience had more negative attitudes toward inclusive education (Savolainen et al., 2012). A possible explanation for this might be that younger teachers have had more opportunities for training on inclusive education in their teacher education programs. It has been suggested that pre-service teachers who had more training on special needs education showed more positive attitudes toward inclusive education (Forlin et al., 2015). Another possible explanation is that 
teachers' attitudes became more negative through their teaching career because they have had difficulty including children with disabilities. Further studies on this topic will need to be undertaken. The most important finding was that efficacy in collaboration with other school staff and parents was the strongest predictor of general attitudes toward inclusive education. As Savolainen et al. (2012) suggested, not only pedagogy but also collaboration skills should be emphasized in future pre- and in-service teacher training. Furthermore, Fujii (2014) found that principals and vice principals had a deeper understanding of inclusive education in Japan. Therefore, collaboration between teachers and leadership groups could be one possibility in developing the inclusive system in schools. Collaboration with parents is also a crucial element in improving an inclusive environment. However, as mentioned above, Japanese teachers spent less time collaborating with parents compared to teachers in other OECD countries, even though Japanese teachers had the longest working hours (NIER, 2014). The government or policymakers should devise a system to reduce teachers' workload so that teachers can allocate enough time to collaborate with other school staff and parents. Another important finding was that self-efficacy in managing behavior was a powerful predictor of attitudes toward inclusive education in the Japanese sample. This result was inconsistent with other countries, such as South Africa and China, in which self-efficacy in collaboration was the only predictor of attitudes (Malinen et al., 2012; Savolainen et al., 2012). It is crucial to develop Japanese teachers' skills in pre- and in-service training in managing challenging student behavior in order to positively alter teachers' attitudes toward inclusive education. Teacher education programs and in-service training should introduce courses aimed at a comprehensive understanding of disabilities and behavior management, which would optimally include concrete practical sessions. Opening up opportunities to gain successful experience to work with students of diverse educational needs is likely to affect teacher efficacy and change their attitudes toward inclusive education more positively. Schoolwide Positive Behavior Interventions and Supports is an example of an international approach based on an inclusive education philosophy, which would have a great deal to offer Japanese teachers (Horner, Sugai, \& Anderson, 2010).

\section{Conclusion}

The present study has shown that although the Japanese government promotes inclusive education, teachers have significant concerns about including children with disabilities in their own classrooms. Since it is assumed that effective inclusive education teachers need to have positive attitudes toward inclusive education (Avramidis \& Norwich, 2002; Forlin et al., 2010), it is important to take measures to change teachers' attitudes, especially regarding concerns about inclusive education. One way of changing teachers' attitudes is to improve their self-efficacy for inclusive practices. The second major finding was that teachers' self-efficacy for inclusive practices was quite low in Japan 
compared to that in other countries, particularly regarding managing problematic student behavior. The results of this study indicate that more attention should be paid to teachers' lack of confidence regarding inclusive practice.

\section{Limitations and implications for practice}

There are a few noticeable limitations of the current study. First, even though an effort was made to include a wide variety of schools from different regions in Japan, the data were collected using convenience sampling. Thus, the findings cannot be generalized to the total population of Japanese in-service teachers. Second, in this study, the types (e.g., public schools or private schools) and levels (e.g., primary or secondary) of the schools in which teachers were working were not considered; nevertheless, there might be differences in teachers' attitudes and self-efficacy across these distinctions. Third, the questionnaire used in this study was translated from English to Japanese. While the equivalence between the two versions was carefully checked in the translation and reviewing processes, it is possible that some of the items in the Japanese version do not describe the same essence of those in the original version. Forth, since a cross-sectional analysis was applied in the current study, the correlation between teachers' self-efficacy for inclusive practices and attitudes toward inclusive education should be interpreted with caution. It is possible that the situation may provide differing results if another timeframe was chosen. Thus, a longitudinal analysis would give us more accurate insights about what kinds of contextual factors affect teachers' attitudes toward inclusive education and self-efficacy for inclusive practices as well as how attitudes and self-efficacy beliefs change over time. Finally, even though the questionnaire yielded psychometrically useful data, it could not elucidate the entirety of the situation regarding teachers' attitudes toward inclusive education and self-efficacy for inclusive practices. Further research in this direction using a qualitative method, such as interviews or observations, would offer more in-depth insights into teachers' perception of inclusive education.

As discussed in the introduction, global changes in educational policies on inclusive education have proceeded rapidly in Japan. However, there are significant gaps between the theoretical level of these policies and the educational practices, which are reflected in teachers struggling with applying inclusive education strategies in their own practices. This is the first study to investigate Japanese teachers' attitudes toward inclusive education and self-efficacy for inclusive practices. The current findings contribute to a more comprehensive understanding of teachers' situation and provide insight into how to improve teacher training for inclusive education. It is suggested that the government should organize teacher training so that teachers can develop skills for collaboration, for managing students' problematic behavior, as well as for pedagogy through pre- and in-service training. In 
addition, teachers' workload, including teaching, club supervision, and clerical work, should be reduced so that teachers could allocate sufficient time for collaboration, which is crucial for inclusive education. Making inclusive education happen in reality also requires changes to the student environment (e.g., classrooms, teaching approaches) in Japan, which in turn necessitates changes in teacher education conditions so that teacher students can learn to become inclusive teachers and appreciate where they will work.

\section{References}

Alghazo, E. M., \& Gaad, E. E. N. (2004). General education teachers in the United Arab Emirates and their acceptance of the inclusion of the students with disabilities. British Journal of Special Education, 31, 94-99.

Allport, G. W. (1935). Attitudes. In C. Murchison (Ed.), Handbook of social psychology (pp. 789844). Worcester, MA: Clark University Press.

Artiles, A. J., \& Kozleski, E. B. (2007). Beyond convictions: Interrogating culture, history, and power in inclusive education. Journal of Language Arts, 84(4), 351-358.

Avramidis, E., \& Norwich, B. (2002). Teachers' attitudes towards integration/inclusion: A review of the literature. European Journal of Special Needs Education, 17(2), 129-147.

Bandura, A. (1977). Self- efficacy: Towards a unifying theory of behavioral change. Psychological Review, 84(2), 191-215.

Bandura, A. (1997). Self-efficacy: The exercise of control. New York: Freeman.

Bandura, A. (2001). Social cognitive theory: An agentic perspective. Annual Review of 
Psychology, 52(1), 1-26.

Bandura, A. (2006). Adolescent development from an agentic perspective. In T. Urdan, \& F. Pajares (Eds.), Self-efficacy beliefs of adolescents (pp. 1-43). Charlotte, NC: Information Age.

Bohner, G., \& Dickel, N. (2011). Attitudes and attitude change. Annual Review of Psychology, 62, $391-417$.

Central Council for Education. (2005). Tokubetsushienkyoiku wo suishin suru tame no seido no arikata ni tsuite [A report about the status of the system in order to promote the special needs education]. Retrieved on 23 March, 2015 from: http://www.mext.go.jp/b_menu/shingi/chukyo/chukyo0/toushin/05120801/all.pdf

Committee of Elementary and Lower Secondary Education in the Central Council for Education. (2012). Kyoseishakai no keisei ni muketa inkuru-shibukyoikushisutemukochiku no tame no tokubetsushienkyoiku no suishin [A report about the development of special needs education in order to construct inclusive education system toward creating co-existent society]. Retrieved on 17 March, 2015 from:

http://www.mext.go.jp/b_menu/shingi/chukyo/chukyo0/gijiroku/_icsFiles/afieldfile/2012/07/2 4/1323733_8.pdf

Eagly, A. H., \& Chaiken, S. (1993). The psychology of attitudes. Fort Worth, TX: Harcourt, Brace, 
Jovanovich.

Engelbrecht, P., Savolainen, H., Nel, M., \& Malinen, O. (2013). How cultural histories shape South African and Finnish teachers' attitudes towards inclusive education: A comparative analysis. European Journal of Special Needs Education, 28(3), 305-318.

Finnish Advisory Board on Research Integrity. (2012). Responsible conduct of research and procedures for handling allegations of misconduct in Finland. Retrieved on 5 July, 2016 from: http://www.tenk.fi/sites/tenk.fi/files/HTK_ohje_2012.pdf

Forlin, C. (2013). Issues of inclusive education in the 21 st century. Gakushu Kaihatsugaku Kenkyu, 6, 67-81.

Forlin, C., Cedillo, I., Romero-Contreras, S., Fletcher, T., \& Hernandez, H. (2010). Inclusion in Mexico: Ensuring supportive attitudes by newly graduated teachers. International Journal of Inclusive Education, 14(7), 723-739.

Forlin, C., Earle, C., Loreman, T., \& Sharma, U. (2011). The sentiments, attitudes, and concerns about inclusive education revised (SACIE-R) scale for measuring pre-service teachers' perceptions about inclusion. Exceptionality Education International, 21(3), 50-65.

Forlin, C., Kawai, N., \& Higuchi, S. (2015). Educational reform in Japan towards inclusion: Are we training teachers for success? International Journal of Inclusive Education, 19(3), 314-331. 
Fujii, Y. (2014). Inkuru-shibukyoikushisutemukochiku no hokosei ni kansuru kento: Kyoshokuin ni taisuru ki-wa-do no ninchidochosa wo toshite [Study into the directions in building the inclusive education system: Through teaching staff survey on keyword awareness]. Bulletin of Center for Educational Research and Practice, Akita University, 36, 89-98.

Gawronski, B. (2007). Editorial: Attitudes can be measured! But what is an attitude? Social Cognition, 25(5), 573-581.

Gibson, S., \& Dembo, M. H. (1984). Teacher efficacy: A construct validation. Journal of Educational Psychology, 76(4), 569-582.

Graham, L. J., \& Jahnukainen, M. (2011). Wherefore art thou, inclusion? Analysing the development of inclusive education in New South Wales, Alberta and Finland. Journal of Education Policy, 26(2), 263-288.

Groves, R. M., Fowler Jr, F. J., Couper, M. P., Lepkowski, J. M., Singer, E., \& Tourangeau, R. (2009). Survey methodology (Vol. 561). New York: John Wiley \& Sons.

Guskey, T. R., \& Passaro, P. D. (1994). Teacher efficacy: A study of construct dimensions. American Educational Research Journal, 31(3), 627-643.

Hamaya, N. (2006). Shogakkotsujogakkyu ni okeru junkaisodan ni yoru keidohattatsushogaiji tono kyoikujissen heno sienmoderu [Using itinerant consultation to support teachers in inclusive 
elementary schools: A model]. Japanese Journal of Educational Psychology, 54(3), 395-407.

Hirose, Y., \& Tojo, Y. (2002). Tsujo no gakkyu ni okeru jiheishoji no kyoiku no genjo (2): Koko no jiheishoji no tokucho to tannin no ni-zu [Current situation of education for children with autism in regular classes (2): Features of individual children and teacher needs]. Bulletin of the National Institute of Special Education, 29, 129-137.

Horner, R. H., Sugai, G., \& Anderson, C. M. (2010). Examining the evidence base for school-wide positive behavior support. Focus on Exceptional Children, 42(8), 1-14.

IBM [The International Business Machines Corporation] (2012). SPSS software. Retrieved on 3 November, 2015 from: http://www-01.ibm.com/software/analytics/spss/

Jahnukainen, M. (2011). Different strategies, different outcomes? The history and trends of the inclusive and special education in Alberta (Canada) and in Finland. Scandinavian Journal of Educational Research, 55(5), 489-502.

Kinsella, W., \& Senior, J. (2008). Developing inclusive schools: A systemic approach. International Journal of Inclusive Education, 12(5-6), 651-665.

Klassen, R. M. (2004). Optimism and realism: A review of self-efficacy from a cross-cultural perspective. International Journal of Psychology, 39(3), 205-230.

Malinen, O., \& Savolainen, H. (2008). Inclusion in the east: Chinese students' attitudes towards 
inclusive education. International Journal of Special Education, 23(3), 101-109.

Malinen, O., Savolainen, H., \& Xu, J. (2012). Beijing in-service teachers' self-efficacy and attitudes towards inclusive education. Teaching and Teacher Education, 28(4), 526-534.

Meijer, C. J. W., \& Foster, S. F. (1988). The effect of teacher self-efficacy on referral chance. The Journal of Special Education, 22(3), 378-385.

Ministry of Education, Culture, Sports, Science and Technology in Japan. (2012). Tokubetsu shien kyoiku shiryo: Heisei 23 nen-do [Special needs education statistics: 2012]. Retrieved on 31 March, 2014 from: http://www.mext.go.jp/a_menu/shotou/tokubetu/material/1322973.htm Miyoshi, M. (2009). Tokubetsushienkyoiku to inkuru-shibukyoiku no setten no tankyu: Nihon ni okeru inkuru-shibukyoikuteichaku no kanosei [A study on contact between special needs education and inclusive education: Possibility of establishment of inclusive education practice in Japan]. Department Bulletin of Human and Environmental Studies, Kyoto University, 18, $27-$ 37.

NIER [The National Institute for Educational Policy Research]. (2014). Kyoinkankyo no kokusaihikaku: OECD kokusaishidokankyochosa (TALIS) nisenjusannen chosakekkahokokusho [International comparison of teacher environment: A result report of Teaching and Learning International Survey (TALIS) 2013]. Tokyo, Japan: Akashishoten. 
OECD [The Organization for Economic Cooperation and Development]. (2011). Education at a glance 2011 (Table D2.1). Retrieved on 27 January, 2014 from: http://dx.doi.org/10.1787/888932465170

Ogiso, H., \& Tsuzuki, S. (2016). Tokubetsushienkyoikutaisei to inkurushibukyoikushisutemu ni kansuru ichikosatsu [Consideration on the special support education system and inclusive education system]. Shogaishakyoiku •fukushigakukenkyu, 12, 155-163.

Oliver, M. (1996). Understanding disability: From theory to practice. New York: St. Martin's Press. Oohara, S., Hirota, E., \& Suzuki, T. (2011). Inkuru-shibukankyo (yojikyoiku/hoikushisetsu) ni okeru tyokakushogaiji no shakaitekiasobi to komyunike-shonjokyo oyobi kanrenyoin no kento [Social play, communication and relative factors of deaf children in inclusive environment (preschool education/day-care institutions)]. Audiology Japan, 54(3), 230-238.

Ryan, T. G., \& Gottfried, J. (2012). Elementary supervision and the supervisor: Teacher attitudes and inclusive education. International Electronic Journal of Elementary Education, 4(3), 563-571.

Savolainen, H. (2009). Responding to diversity and striving for excellence: The case of Finland. Prospects, 39(3), 281-292.

Savolainen, H., Engelbrecht, P., Nel, M., \& Malinen, O. (2012). Understanding teachers' attitudes and self-efficacy in inclusive education: Implications for pre-service and in-service teacher 
education. European Journal of Special Needs Education, 27(1), 51-68.

Sharma, U., Loreman, T., \& Forlin, C. (2012). Measuring teacher efficacy to implement inclusive practices. Journal of Research in Special Educational Needs, 12(1), 12-21.

Takala, M., Haussttatter, R. S., Ahl, A., \& Head, G. (2012). Inclusion seen by student teachers in special education: Differences among Finnish, Norwegian and Swedish students. European Journal of Teacher Education, 35(3), 305-325.

Ueno, K., \& Nakamura, K. (2011). Inkuru-jonkyoiku ni taisuru tsujogakkyukyoin no ishiki ni tsuite [A study of awareness of "Inclusion Education" among regular-class teachers in elementary schools]. Journal of Health and Sports Science Juntendo, 3(2), 112-117.

UNESCO [The United Nations Educational, Scientific and Cultural Organization]. (1990). World declaration on education for all and framework for action to meet basic learning needs.

Retrieved on 27 July, 2015 from: http://www.ifa.de/fileadmin/pdf/abk/inter/unesco_jomtien.pdf UNESCO. (1994). The Salamanca statement and framework for action on special needs education. Retrieved on 8 May, 2014 from: http://unesdoc.unesco.org/images/0009/000984/098427eo.pdf UNESCO. (2000). The Dakar framework for action: Education for all: Meeting our collective commitments. Retrieved on 27 July, 2015 from: http://www.undp.org.lb/programme/governance/institutionbuilding/basiceducation/docs/dakar.p 
df

UNESCO. (2005). Guidelines for inclusion: Ensuring the access to education for all. Retrieved on 9

June, 2014 from: http://unesdoc.unesco.org/images/0014/001402/140224e.pdf

UNICEF [The United Nations Children's Fund], General Assembly. (1989). Convention on the

rights of the child (Resolution 44/25, annex). Retrieved on 5 July, 2016 from:

http://www2.ohchr.org/english/law/pdf/crc.pdf

United Nations. (1989). Convention on the rights of the child. Retrieved on 31 January, 2017 from:

http://www.ohchr.org/Documents/ProfessionalInterest/crc.pdf

United Nations. (2006). Convention on the rights of persons with disabilities. Retrieved on 2

November, 2015 from: http://www.un.org/disabilities/documents/convention/convoptprot-e.pdf

Waitoller, F. R., \& Artiles, A. J. (2013). A decade of professional development research for inclusive education: A critical review and notes for a research program. Review of Educational

Research, 83(3), 319-356.

Weisel, A., \& Dror, O. (2006). School climate, sense of efficacy and Israeli teachers' attitudes toward inclusion of students with special needs. Education, Citizenship and Social Justice, 1(2), $157-174$.

Yoshitoshi, M. (2014). Inkuru-shibukyoiku ni taisuru kotogakkokyoin no jikokoryokukan: 
Tokubetsushienkyoikuko-deine-ta- wo taisho toshita shitsumonshichosa no bunseki [A survey of Japanese high school teachers' self-efficacy about inclusive education]. Bulletin of Center for

Teacher Education and Development, Okayama University, 4, 1-5. 